International Journal of Engineering \& Technology, $7(4.38)(2018) 861-865$
International Journal of Engineering \& Technology
WPC
Website: $w w w . s c i e n c e p u b c o . c o m / i n d e x . p h p / I J E T$
Research paper

\title{
Sex, Sin and Marriage: Feminists in Patriarchal Culture, Religious Values and the Struggle for the Equality
}

\author{
Dr. Nuriyati Samatan
}

University of Gunadarma. Republic of Indonesia

\begin{abstract}
Sex, Sin and Marriage: Feminists in Patriarchal Culture, Religious Values and the Struggle for the Equality, is a study conducted on the novel Eks Parasit Lajang by Justina Ayu Utami. The approach of this research is qualitative with Critical Analysis of Frankfrut School method through four levels of analysis: Totality, Awareness, Alienation and Criticism. The results of this study show that in the level of totality, Ayu Utami sees the problems experienced by character A as a problem that not only comes from herself, but also from her family who embrace Patriarchal culture, religious values, and also the values come from the society. In the level of Awareness, Ayu Utami sees that the world is constructed by men, and marriage as a mean of legitimizing power (patriarchal); in the level of Alienation, Ayu Utami is alienated from the concept of the church which is considered problematic; about herself and her sexual organs; about the values of women and marriage, until she decides to "take off the Cross's necklace" and ends up "deciding not to have any religion". In the Criticism level, Ayu Utami criticizes her religion's "Holy Book", Patriarchal culture and also criticizes on the State regulations which she considers unfair especially in marriage arrangement as well as the society values which are considered confining and disadvantaging women, but not for men.
\end{abstract}

Keywords: Sex Sin and Marriage, Feminist, Patriarchal culture, Religious Values, Equality

\section{Introduction}

This paper aims to break the thought of one of the Indonesian Feminist pioneer, Justina Ayu Utami, in her novel entitled Eks Parasit Lajang. This novel tells about the autobiography of Ayu Utami's sexuality and spirituality. This (real) story is written in a novel form whose character is initialized $\mathrm{A}$, a woman who decides to give her virginity up at the age of twenty as well as to erase the concept of virginity at once which is unfair to her. This novel is a trilogy of two previous titles: "Si Parasit Lajang", "Cerita Cinta Enrico", and the third book is "Pengakuan Eks Parasit Lajang". The authors choose the novel Pengakuan Eks Parasit Lajang as the object of the research based on the updated work of Ayu Utami which is reissued by Kepustakaan Populer Gramedia in February 2013 as the autobiography of Ayu Utami and the main consideration is that Ayu Utami's works have gained appreciation. For example, her work "Saman" has received international appreciation as one of the winners of the Prince Clause Award in 2002. In addition, this novel tells about the phenomenon of Indonesian women referring to the perspectives of the Feminists in representing the conditions of social, cultural and religion that are considered to confine women and cause gender inequalities in society. The discussion will refer to the Critical Analysis of Frankfrut School, namely: Totality, Awareness, Alienation and Criticism $[8,15]$.

\section{Discussion}

Ayu Utami's Eks Parasit Lajang is one of the novels that represents the rights fought by the Feminists, which is the equality of women's rights that has always been the subordinate of men.
The novel has been widely contesting some "established" norms in Indonesian society caused by the Patriarchal Culture, religious values and are also reinforced by governmental rules - especially during the New Order [12].

In Indonesia, feminist theology has become an academic discourse although the numbers are still small. It shows a serious effort to fight the legitimacy of violence against women through religion, culture and state policy. Not only through some academic and research courses, feminist theology also strives for the struggle through literature. [1] 2016, in his work entitled Rekonstruksi Citra Perempuan Dalam Alkitab in the collection of Perempuan Yang Dihapus Namanya by Avianti Armand in Proceedings of the International Conference on Feminism: Crossing Identities, Agencies and Politics (20 years Journal of Women), Jakarta: Women's Journal Foundation, argued that the plan and struggle of the Feminists has been done much earlier. In 1611, Aemilia Lanyer wrote In Salve DeusRex Judaeorum. The collection of poetry and prose is considered the earliest work that discusses feminist theology. The poetry relates to important events in the Bible, both of Adam and Eve to the crucifixion of Christ. The work is considered as a revision of what commonly becomes the general thought about women in religion, that women are posterior et inferior (last and lower). Agnieszka Markiewicz (2005, in [1] 2016) sees that this work becomes Lanyer's attempt to reconstruct or give new perspectives about women in the Bible. $[14,1]$ is considered more specific; seeing from the terms of sexuality and the idea of divinity in this work. Diane Purkiss as quoted by [7] says through her work that Lanyer has created an "interpretive community of female virtue" which gathers the power of women as readers to show their strength. 


\subsection{Perspectives of Sex in the novel Eks Parasit Lajang}

Sex in the novel Eks Parasit Lajang is a coitus or sexual activity, as Ayu Utami expressed in the early part of this novel:

"You're a map, as people say, longing to be explored. You are a damp forest that holds the desire to be explored. You are an unsteady tip to be stung by lightning. Tips which are waiting to be harvested. Your lust melts, can not hide. That is the sense of knowledge" [11].

In this dialogue, Ayu Utami courageously expressed what she felt about sexual lust that has not been vented through sexual activities and then she called it as a "melting" lust to describe the next phase when she had sexual activities.

"I have wanted it: to be an object - or a subject?, to be known - or to know?, to be a map to be explored, a stinging tip, an exposed forest. At the age of twenty I decided to give my virginity away" [11].

The sentences above show that Ayu Utami had made a dichotomy in sexual activities; activities that have been identified as activities that are always wanted by men where women become the object. Sexual activities - especially for single women - are considered sacred and taboo to be discussed, but Ayu Utami revealed vulgarly to the surface; and also boldly challenged "tradition": (1) Talks about sexuality; and (2) Consciously revealing, "I decided", "give my virginity up". These sentences show full awareness because character A "decides". The meaning behind the "decisions" are: (1) that character A is consciously and without any coercion "decides" to "give her virginity up" as known as "have the sexual activity before getting married and give her virginity to a man, which in the novel is identified as "lover A".

These sentences also state about "deciding to give her virginity up," indicating that while doing sexual activity with her lover, character A is not in a state of distress over her superior lover, but "consciously decides" to engage in it. This provides an understanding that there was no "physical mastery" on her - as stated by Fakih[5], that male's physical mastery of women is the basic form of oppression; and also the "female body" is "the main object of oppression" [16]. Ayu Utami affirms about the "body" that is not in any "oppression"; the "body" which is in her own control. Based on the Liberal Feminist perspective, Ayu Utami says that female equality means free from the oppressive restrictions imposed by sex, self-determination and autonomy. Free from the oppressive restrictions imposed by sex means free from biological and societal restrictions. Self-determination means someone is free to decide his/her own destiny, free to define one's social role, to have the freedom to make decisions regarding one's body. Autonomy means a person obtains his or her own status, not being born into it or marrying it, and it also means financial independence, free to choose any lifestyle, all of which imply a radical transformation of existing institutions, values and theories [2].

\subsection{Perspectives of Sin in the novel Eks Parasit Lajang}

In general, sin is defined as human actions that violate God's commandments, norms and rules in all aspects of life, either those relating to a profane world life or a sacred hereafter, especially regarding to theological, worship, moral, etc. Sin, either it is big or small, implies to the 'destruction' of the relationship between mankind and God as well as with fellow human beings, the universe and other God's creatures [13].

Another word for sin is avon which means evil, mistake, or punishment rooted in a nucleus that means regret. The word resta is usually translated as a violation used within the limits of rebellion. The word haya is a keyword and often used for the term sin which means removes (the path). The meaning of sin seems to eliminate the right path that matches for the term regret [4].
In the novel Eks Parasit Lajang, the "sin" that character A had committed is during the sexual activity at the age of twenty with her lover Nik:

"In the meantime, Nik is now my lover when I'm twenty and I feel right to give my virginity. I want to do it with Nik, though I'm not really sure about my decision yet. We both actually come from a religious family. Giving up virginity before marriage contract is never a teaching in our family" [11].

In the sentences above, there is a duality expressed by Ayu Utami: Between pre-marital sexual activity of character A and her lover Nik, and second is about "giving up virginity before marriage contract" which she claims to be something "...that is never a teaching in our family's religion." The acknowledgment of "sin" is emblazoned with the last sentence in the paragraph, that it is never a teaching in our family's religion (Catholic), but it is not necessarily followed by the character A. Sin according to the concept of Catholicism is against the ten commandments of God, but beyond that, there is still a sin that has been attached to humans since birth. That special sin is the original sin which is the sin of Adam and Eve. Once born into the world, humans already bear the burden of sin on their shoulders [9]. In the end, to face the problem of the first sin, religion will show its identity and role as a community that believes in the deliverance of sin that does not come from oneself [6]. The Ten Commandments [9], consists of (1) I am the Lord, your God: There is no other God before Me. Do not make for yourself a statue that resembles whatever it is in the heavens and the earth and do not bow down to worship it (Verses 2,3,4,5); (2) Do not call the name of the Lord disrespectfully (Verse 7); (3) Remember and keep the Sabbath day holy (Verse 8); (4) Honor your father and your mother (Verse 12); (5) Do not kill (Verse 13); (6) Do not commit adultery (Verse 14); (7) Do not steal (Verse 15); (8) Do not reveal false witnesses of your neighbor (Verse 16); (9) Do not covet your neighbor's wife (Verse 17a); and (10) Do not covet your neighbor's property (Verse 17b).

\subsection{Perspecives of Marriage in the novel Eks Parasit Lajang}

Wedding is a ceremony that is celebrated or performed by two persons with the intention of validating a bond. By law, stated in the Act of Republic of Indonesia Number 1/1974 Chapter 1 Article 1 that 'marriage is an inner and outer bond between a man and a woman as a husband and a wife in order to establish a happy and lasting family following The Divinity'. According to the Catholic church, "Marriage is a communion of life and love between a husband and a wife which tenderly held by the Creator and qualified by His laws, built by the marriage contract or private agreement that can not be withdrawn. The sacred bond for the welfare of the husband and wife and of the child as well as the society does not depend on the will of mere humans. God is the Creator of marriage which includes a range of values and objectives "(quoted from Kasih Setia Dalam Suka-Duka, Pedoman Perkawinan di Lingkngan Katolik, 1993).

In addition, [3] also reveals two reasons of why women should marry. The first reason is that women should give offspring in the society. The second reason is that the function of women is also to satisfy the sexual needs of male partners as well as taking care of her husband's needs. Such marriage would still benefits men. Thus, [3] reveals the economic evolution where women are in the process of disrupting the institution of marriage; economic evolution becomes an entity that freely enters into an agreement between two independent people; the obligations between the two committed parties is personal and mutually beneficial.

Marriage, in Ayu Utami's mind, reflects the gender imbalances in two places: First, on the subject-object relation; and Second on the "destiny" which women have to live in, the helplessness of women who have to take care of their "virginity" or "to be exchanged if the seal is broken". Being virgin is a must for women 
or they will be "exchanged" if they have lost their virginity. As stated by character A's mother in the novel:

"Then the women are ready to be sent to earth. As a product for male consumption. Men buy them. If the virginity is lost, the man has the right to trade it. Q Cola

My mother once said that women are like porcelain. If it's broken, it becomes worthless. She did not say it in a patronizing tone, but more in a grim and helpless tone" [11].

Furthermore, Ayu Utami is also suing a marriage which she considers very beneficial to men and harms women, as the following quotes:

"1. Husband / father is the leader or the head of the family. 2. Men can have many wives, women are not allowed to have many husbands. 3. The ownership of land and goods is on the husband. 4. Wife must ask permission from the husband, but not otherwise. 5. Wife loses her family name and uses her husband's name. 6. It is easier for husbands to divorce their wives than otherwise. 7. Children born from unmarried women shall be punished by labelling them as illegitimate child. (This list can be extended).

...Thus, women are incorporated into a marriage system in which they become dependent on men " [11].

Aside from being the subordinate in the family suffered by women, when people are married, some privileges are given to men and one of the institutions in which the Patriarchal power lies in marriage.

Women are also being "disadvantaged" in Ayu Utami's perspectives with the existence of polygamy as many Indonesians (especially Muslims) do, while polygamous men do not accept the concept of "polyandry". This is very disavantageous to women, and shows the inequality of rights between men and women.

\subsection{Totality}

Totality, in Criticism Theory of Frankfrut School, is described as: "The notion that any understanding of society must embrace in their entirety the objective and the subjective world which characterizes a given epoch. Totality embraces everything; it has no boundary. An understanding of this totality must precede an understanding of its elements, since the whole dominates the partin an all-embracing sense [8].

Ayu Utami's Eks Parasit Lajang shows a totality of meaning towards the world that encompasses it, both subjective and objective world. According to her, many inequalities experienced by women are due to religious values as well as patriarchal culture rooted in the surrounding community.

During college, she started to have relationship with two men. She has give her virginity to one of the two men because for her the deeds categorized "sin" in the religious and cultural norms of society is as the following quote:

"I did not find fault or injustice in the ban. The problem is the religion itself that is problematic. The prohibition of adultery may not be very problematic, but religion is problematic. Religion builds unfair values to women in general. Prohibit women from becoming leaders. Make men the leaders for women. Religion raises itself over poeple's fear. Religion spreads threats and becomes the basis of violence. And practically, many cases of religious leaders are corrupt in terms of morals and money. Many priests have been involved in pedophilia scandals. I decided to no longer have a religion "[11].

Besides, character A also questioned about relation and marriage that requires her to convert, following her lover's religion which is Muslim:

"Why should I change my religion? Why don't you just convert? I say. Even though our father convert to our mother's religion, I've never wanted to change someone's religion, let alone the person I love. I have an ideal to love people for what they are. It's just a test of balance. If he thinks we have to have the same religion, why should I be the one to convert?" [11].

The sentences in this paragraph are a critique for the government which is against the regulations made through the Marriage Act as well as on the religious rules which has limited someone's space; in choosing a partner and making a relationship with whom she/he wants.

\subsection{Awareness}

Awareness in the Critical Paradigm of Frankfrut School is described as:

"The force wich ultimately and sustains the social world. Consciousness is internally generated but influenced by the form of the process of objectivity and the dialectic between subjective and objective worlds [8].

The first awareness of "the world constructed by men" occurs to character A in her family life which reckons her father as a representation of the patriarchal concept. As she steps out, a similar awareness of the surrounding partiarchal culture is represented in this novel which is the reality that his two aunts

"That was the point that changed my life: I saw a huge wound; so big that it swallows women. That was the point where I began to think about not getting married and pointing out that there is nothing that diminishes women's dignity because of it.

Regarding my two aunts, I'm really sad. I saw the shadows of monsters. And the frightening creature left in my family. My aunts were the vaccines that made my body system create its own antibodies. My antibody immediately detects who the enemy is. The enemy that has caused wounds and jealousy to sprinkle in the bodies of my two aunts (and the bodies of many women) and then devoured them.

It has detected the enemy and now is working to destroy the two main enemies: one, virginity. Two, marriage " [11].

The sentences above illustrate how character A decides not to marry. Character A does not marry because she feels that there is a wound on the woman and she wants to show the public that the woman who chooses not to marry does not diminish her dignity. At the end of the story in this novel, it is told that character A finally decides to marry. However, the marriage that she had was in Catholic procedure without following the state procedure. She declared it when she was in a church community when she was having discussions with the priest of the church.

"Now, Father A makes her think about something else. It's initially simple: character A gladly invited to show some things that she thinks are important among Catholics. But she knew she could be a thorn in the flesh at each Mass. There could be people protesting: The A is living together without getting married, blatantly challenging as well, she won't be allowed to welcome the Body of Christ! The only way she can receive the communion without giving a dilemma to others is with the Sacrament of Marriage. But, does that mean she must marry?"[11].

In the dialogue above, it is explained how character A was initially invited by the priest to campaign about the Catholic community. Her participation in the community made her realize that she had become a thorn in her own community. She realized that when it is viewed from the rules that tought by the church, she had violated one command of God. Besides, while following all the rituals of worship, character A felt guilty to be allowed to welcome the body of Christ as the host was distributed. Since then, she started thinking about marriage. She thought that if she married, she could follow all the activities of his community.

\subsection{Alienation}

Alienation, in the Critical Paradigm of the Frankfrut School, is defined as: 
"The state in which, in certain totalities, a cognitive wedge is driven between man's conclusion and the object of social world, so that man is the dominating, external reality. This wedge is the wedge of alienation, which divorces man from his true and hinder the fulfillment of his potentialities as a human being" [8].

One of the "alienations" thich can be observed in the novel $E k s$ Parasit Lajang is the alienation of character A who represents Utami against the values that surround her. The values which exist in the church dogma as a Catholic as well as the values in society. One of the "alienations" is revealed in the following sentences:

"Of all the human burrows, of course that one channel is the least used since infancy. Nose to breathe. Then the membranes there have been torn since you cried. Ear to hear. Rectum, ah, it's been active since the fetus is still in the womb. So have the mouth and urinary tract. Only vagina that entirely does not work during childhood. It's a sleeping organ. So it's natural if it is filled with traces. Like a cobweb attached to an abandoned space" [11].

The sentences show that, for Ayu Utami, the hymen "is merely" one of the "channels" between the other "channels" within human beings since birth. Just like "other channels", doing some "activation" with it becomes common and it is up to the owner to use it whenever she/he wants to. As in the Liberal Feminist perspective, "the freedom to use or not to use it" is a form of "equality", when women are free from the oppressive restrictions imposed by sex, self-determination and autonomy; free from the oppressive restrictions imposed by sex means free from biological and societal restrictions. Self-determination means one is free to decide one's own destiny, free to define one's social role, to have the freedom to make decisions regarding one's body [2]

The public's perspective and religious values of sex - in this case is a relationship outside of marriagecontract, have made Ayu Utami to"must take off the Cross" as a symbol of a person as a believer and believes in her religious teachings:

"So, at the age of twenty, I took my Cross necklace off. I have kept my distance from religion. All religions. The unjust attitude I've done still haunts me, but sin can no longer scare $m e^{\prime \prime}[11]$.

Alienation is also felt by character $\mathrm{A}$ in her own family which against her unmarried aunts who are considered "victims" of "values" in their own society:

"My two aunts probably have their own basic conceit. Every human being has a weakness. But at some point, they are victims of the society values (which are also embraced by themselves). Values which consider women to be dignified only if they get tthe status of Mrs. X, especially Mrs. Official $X$. Now, they are adrift with no status. That's the first" [11]. In addition to character A's alienation of sex matter, as well as unmarried women and causing problems within themselves, Ayu Utami is also "alienated" from her religion and then decides to "take off the Cross necklace" as a symbol of breaking the attachment of "religious values" in her because of the "deeds considered sinful" by the Church:

"So, at the age of twenty, I took my Cross necklace off. I have kept my distance from religion. All religions. The unjust attitude I've done still haunts me, but sin can no longer scare me" [11].

Ayu Utami assumes that banning system done by the churches with the label "sin" for those who do it is a form of religion's injustice against women which is considered unfair:

"I did not find fault or injustice in the ban. The problem is the religion itself that is problematic. The prohibition of adultery may not be very problematic, but religion is problematic. Religion builds unfair values to women in general. Prohibit women from becoming leaders. Make men the leaders for women. Religion raises itself over poeple's fear. Religion spreads threats and becomes the basis of violence. And practically, many cases of religious leaders are corrupt in terms of morals and money. Many priests have been involved in pedophilia scandals. I decided to no longer have a religion "[11].

The culmination of Ayu Utami's alienation is when she decided to "no longer have a religion", as she put it in the novel: "...I decided to no longer have a religion "[11]. The decision to have a religion or not is a personal decision, but as a Catholic descendant and is educated and raised under the values and norms of that religion, the decision to have "no religion" is a big decision, because one's diversity is a part of subjective religion which has implications for his/her perspective towards the world as a whole.

\subsection{Critics}

Critics in the Critical Analysis of the School of Frankfrut School is:

"In their critique of contemporary societies, critical theorists focus on the form and sources of alienation, which is what they see as inhibiting the possibilities of true human fulfillment. The various exponents of this perspective approach it in somewhat different ways, at varying level of generality "[8].

Reinterpreting the Bible becomes an important work to liberate women from negative images, discrimination and subordination. As Schäfer [10] says that reinterpretation of the Scriptures is essential to change the position of women from object to subject. Under the conditions of "being the subject", women have the right "to determine their nature as human beings and to demand space for growth". It can be seen how the symbols of theology, especially the Bible, becomes the battle field for feminist theologians.

Ayu Utami's criticisms are also made against the State as well as religious institutions that do not allow any inter-religious marriage, when she could not marry Nik because she had to "convert". Character A in this novel refuses to "convert", although on the other hand, she also criticizes the dogma in her own religion. In addition, this novel also criticizes the norms that are considered "established" in the society, about virginity, stereotype in society in viewing unmarried women; marriage only to raise social status; like her two aunts living in her home pavilion.

Ayu Utami is also suing about "premarital sex" which she thinks is unnecessary and does not deserve such an appraisal. She criticized (angryly) to her father and (of course also) to the society that discredited women's choices.

Patriarchal culture is Ayu Utami's next criticism, about "public leadership"; "leaders in the family" as well as "political leaders", as stated in the following paragraph:

Men are public leaders. Man is the leader of the family. Men are political leaders. Men are the religious women. Men are more rational than women. A not manly man is a sissy. Sissy is a coward. Women are followers. Women are crooked that should be straightened by men. Women are followers. Women can not make decisions so they should be grateful for any decision. Women who earn a living are women who are less grateful. Men gain more inheritance than women. Men can do polygamy, women can not..." [11].

Based on the criticisms expressed by Ayu Utami in the paragraph above, some of which are based on patriarchal culture shared by most Indonesian tribes and others are State rules as well as religious norms. Besides, Ayu Utami criticizes the procreative marriage institutions, married to have offspring, as well as the values that exist in society:"And their anxiety is related to the desire to have children or have a husband" [11]. Here, Ayu Utami criticizes the procreative marriage, the marriage to produce offspring and the desire to have sex wanted by women by having to have a husband. 


\section{Conclusion}

Indonesian women's struggle, especially in terms of equal rights and duties between men and women, involves various efforts and initiations. These efforts have now begun to show the results, although it is not significant. Policy at the government level, since the New Order Government, has been created the Gender Mainstreaming regulation nationally, the issue of gender mainstreaming has existed since 1978 when Suharto was in power, to this day. The issuance of the Presidential Instruction in 2000 on Gender Mainstreaming is an international deal that has encouraged a change of paradigm of women empowerment, from WID (Women in Development) to GAD (Gender and Development).

Ayu Utami, in the novel Eks Parasit Lajang, has represented "unfinished work" of gender mainstreaming or GAD today, although on the other hand, the strength of the pressure given by families, groups and neighborhoods, especially on the religious values she embraces, makes Ayu Utami "choose to make peace" to be more "acceptable" in her environment, and especially to her faith.

\section{References}

[1] Anggradinata, Langgeng Prima. Rekonstruksi Citra Perempuan Dalam Alkitab Pada Kumpulan Puisi Perempuan Yang DihapusNamanya Karya Avianti Armand. Dalam Prosiding Konferensi Internasional Feminisme: Persilangan Identitas, Agensi dan Politik (20 tahun Jurnal Perempuan), Jakarta: Yayasan Jurnal Perempuan: 11 (2016).

[2] Apriani, Fajar. Berbagai Pandangan Mengenai Gender dan Feminisme,Prosiding Konferensi Internasional Feminisme: Persilangan Identitas, Agensi dan Politik (20 tahun Jurnal Perempuan), Jakarta: Yayasan Jurnal Perempuan: 11 (2016).

[3] Beauvoir, Simon de. Second Sex. Terjemahan Febriantono, Toni B.Jakarta: Pustaka Promethea: 225-257 (2003).

[4] Erich, Froom. Manusia Menjadi Tuhan. Yogyakarta: Jalasutra, 224 (2002)

[5] Faqih, Mansour. Analisis Gender dan Transformasi Sosial. Yogyakarta: Pustaka Pelajar, 103 (2012).

[6] Haryatmoko. Dominasi Penuh Muslihat: Akar Kekerasan dan Diskriminasi. Jakarta: Gramedia Pustaka Utama, 110 (2010).

[7] Hodgson-Wright, S. Early feminism. In Gamble, S. (Ed.). (1999) Icon Critical Dictionary of Feminism and Postfeminism (3-15). Cambridge: Icon Books, 12 (1999).

[8] Miller, Katherine. Communication Theories, Perspective, Processes and Contexts. Boston: McGraw-Hills, 64 (2002).

[9] Rahardian, F. 2000. Mengugat Tuhan. Yogyakarta: Kanisius.

[10] Schäfer, (Ed.). Menggugat Kodrat, Mengangkat Harkat: Tafsiran dengan Perspektif Feminis atas Teks-Teks Perjanjian Baru. Jakarta: BPK Gunung Mulia, 11 (2014).

[11] Utami, Ayu. Pengakuan Eks Parasit Lajang. Jakarta: Kepustakaan Populer Gramedia, 8-254 (2013).

[12] Neils. Ruang Bathin Masyarakat Indonesia. Yogyakarta: LKiS, 812 (2013).

[13] Tarpin. Pandangan Kristen Tentang Dosa: Asal Muasal dan Cara Menebusnya. Jurnal Ushuludin Vol.XVI No 2. Jakarta : UIN Ushuludin Jakarta, 221 (2010)

[14] Trill, Suzana. (2001). Feminism versus religion: towards a rereading of Aemili Lanyer's Salve Deus Rex Judaeroum. Journal Renaissance and Reformation, XXV (4), 67-80.

[15] Samatan, Nuriyati. Sosiologi I. Jakarta: Penerbit Gunadarma. 132 (2015).

[16] Tong, Rosemarie Putnam. Feminist Thought. Diterjemahkan dalam Bahasa Indonesia oleh Aquarini Priyatna Prabasmoro. Yogyakarta: Jalasutra, 15-35 (2008). 